\title{
Development of a Modular and Sustainable Yam Pounding Machine
}

\author{
Ibhadode Oisehoemomen ${ }^{1 *}$, Aniekan Essien 1 and Adedoyin Adesuji ${ }^{2}$ \\ ${ }^{1}$ Department of Mechanical Engineering, Federal University of Petroleum Resources Effurun, Delta State, Nigeria \\ ${ }^{2}$ Petroleum and Gas Engineering Department, University of Port-Harcourt, Rivers State, Nigeria
}

*Corresponding author: Ibhadode Oisehoemomen, Department of Mechanical Engineering, Federal University of Petroleum Resources Effurun, Delta State, Nigeria.

Received Date: June 19, 2020

Published Date: July 06, 2020

\begin{abstract}
This work is focused on the design and production of a yam pounding machine. This machine consists of a shaft, electric motor, stainless steel pot, yam beater or blade, pulley and the frame. Mild steel material and stainless-steel sheet were used in the design on its availability, strength, appearance, and cost and corrosion resistance. A power requirement of $1 \mathrm{hp}$ was needed to drive the machine. However, an improvement was made on the size, making it more portable than the existing ones and the use of dampers to minimize vibration with better reliability and working efficiency. The machine was designed, constructed, assembled and tested according to specification. The performance of the machine was evaluated to its highest level of efficiency of $96 \%$ and demonstrated by pounding $3 \mathrm{~kg}$ of cooked yam. The designed machine is far better than the traditional method of pounding yam. It pounds within a short period and little or no human effort is required for the pounding process.
\end{abstract}

\section{Background of the Study}

Yam belongs to the class of carbohydrate type of food and had been one of the oldest recipes known to man. It has been a major food crop in many of the African/ Caribbean'scountries such as Ghana, Ethiopia, Benin Republic and Nigeria in particular. Also, in some other parts of the world such as Brazil, India, Oceania and Latin America; yam is a major source of food. The word "yam" was derived from the Wolof word "nyam" which is a Portuguese name meaning "to taste". Also, in another African language, it means "to eat" e.g. in Hausa"nyam" (Mignouna et al, 2003). This perennial herbaceous crop is of different species such as the white yam (Dioscorea.rotundata), yellow yam (Dioscoreacayenensis), water yam (Dioscoreaalata) and trifoliate yam (Dioscorea. dumetorum) (Amusaet al., 2003). The fruit of yam consists of a membranaceous, three-wing capsule. The yam family is mostly of the weak-stemmed vines with large, underground food storage organs-tuber-rhizomes. Yam has found its use in the preparation of steroid hormones by the syntax synthesis of cortisone from yam extract. Also, its lower glycemic index than potatoes products (kay, 1987) accounts for its more sustainable energy and better protection against obesity and diabetes (Walsh, 2003). Yam pounding machine can be operated by electrical, mechanical and solar means. Best performance with power conversion is possible using Solar technology [1].

According to the food information Network in 2008, it was estimated that the world production of yam in 1993 was at 28.1 million tons in which $96 \%$ of this estimate was from the West Africa tropical regions and $71 \%$ from Nigeria. This figure was later reviewed in 1998 accounting for about $72.4 \%$ of the world total production of 29.6 million tones. Also, according to the Federal Office of Statistics, Nigeria is the world's largest producer of yams having the water yam (Dioscoreaalarta) and the yellow yam (Dioscorearotundata) as her most cultivated species of yam. Yam, being one of the most sumptuous meals, can be prepared in diverse 
ways. While the Yoruba tribe may prefer it dried, milled and then made into a slightly solid paste called "Amala", the Igbos prefer cutting the tuber into smaller blocks or bits, boiled and eaten, in order to avoid the tedious nature of pounding the boiled yam which results to bond formation like Nigeria's locally prepared fufu (Akissoe et al, 2003). However, the process of meshing or beating something into pulp or powder with repeated heavy blows is known as pounding. Yam has remained one of the most highly regarded food products in West Africa and particularly Nigeria as virtually all her ethnic groups feed on it; hence its close integration into the socio-cultural, economic and religious aspect of life such as marriage where some tubers of yam are presented to the bride family in accordance to the customs of the people [2]. Also, Osueke prefers a replacement of the unhygienic and the noisy effect of the classical machines to the number of strokes during pounding to be uncalled for (Osueke,2010). Design improvement is very important in work operation [2,3]. The production process of "POUNDO YAM" consists of simple operations. The unit operations are Yam selection, washing; peeling, slicing and dicing; parboiling; drying; milling, sieving, packaging.

\section{Nutritional value of pounded yam}

A meal of pounded yam with vegetable soup provides a very rich and balanced diet. Yam in itself has been hailed as one of the most nutritious foods known to man. Apart from being rich in fiber protecting the bowels against diseases like diverticulitis, it is a great source of vitamin C, vitamin B6, magnesium, and phosphorus. Yam is also rich in protein. Some pounded yam flour contains sulfites as preservatives. If you are usually allergic to food preservatives, there are chances that you may be allergic to sulfites. A yam pounding machine is been developed using mainly some locally sourced materials. The machine consists of a shaft, pulleys, belt, bearings, electric motor, yam beaters, bowl and the frame. The machine is developed to enhance the hygienic processing of yam for both domestic and commercial consumption while eliminating the tedious and laborious indigenous process of preparing pounded yam. The need for a machine that will pound yam to this needed quality with less human effort and time becomes expedient. The main objective of this work, therefore, is to develop a reliable and efficient yam pounding machine that would be easy to operate and maintain.

\section{Yam pounding machine}

Yam pounding machine is a machine that is designed to perform the task of converting boiled yam into pounded yam. A boiled yam is poured into the pounding chamber and covered; then electric current is supplied which powers the induction motor to transmit the motion to the pounding blade for pounding the yam. The yam pounding machine designed will take over the manual process of yam pounding commonly employed in various homes, which involves the use of mortar, pestle and human efforts. The machine will be designed to do the pounding operation in less than 4 minutes. The aim of this study is the design and production of a yam pounding machine capable of eliminating the noise and vibrations associated with the traditional method of pounding

\section{Review of Literature on Yam Pounding Machine}

Yam belongs to the class of carbohydrate type of food and had been one of the oldest recipes known to man. It has been a major food crop in many of the African/ Caribbean's countries such as Ghana, Ethiopia, Benin Republic and Nigeria in particular. Also, in some other parts of the world such as Brazil, India, Oceania and Latin America; yam is a major source of food. The word "yam" was derived from the Wolof word "n yam" which is a Portuguese name meaning "to taste". Also, in another African language, it means "to eat" e.g. in Hausa "nyam" (Mignouna et al, 2003). This perennial herbaceous crop is of different species such as the white yam (Dioscorea.rotundata), yellow yam (Dioscoreacayenensis), water yam (Dioscoreaalata) and trifoliate yam (Dioscorea. dumetorum) (Amusaet al., 2003). The fruit of yam consists of a membranaceous, three-wing capsule. The yam family is mostly of the weak-stemmed vines with large, underground food storage organs-tuber-rhizomes. Yam has found its use in the preparation of steroid hormones by the syntax synthesis of cortisone from yam extract. Also, its lower glycemic index than potatoes products (kay, 1987) accounts for its more sustainable energy and better protection against obesity and diabetes (Walsh, 2003). According to the food information Network in 2008, it was estimated that the world production of yam in 1993 was at 28.1 million tons in which $96 \%$ of this estimate was from the West Africa tropical regions and $71 \%$ from Nigeria. This figure was later reviewed in 1998 accounting for about $72.4 \%$ of the world total production of 29.6 million tones. Also, according to the Federal Office of Statistics, Nigeria is the world's largest producer of yams having the water yam (Dioscoreaalarta) and the yellow yam (Dioscorearotundata) as her most cultivated species of yam. Yam, being one of the most sumptuous meals, can be prepared in diverse ways. While the Yoruba tribe may prefer it dried, milled and then made into a slightly solid paste called "Amala", the Igbos prefer cutting the tuber into smaller blocks or bits, boiled and eaten, in order to avoid the tedious nature of pounding the boiled yam which results to bond formation like Nigeria's locally prepared fufu (Akissoe et al, 2003). However, the process of meshing or beating something into pulp or powder with repeated heavy blows is known as pounding. Yam has remained one of the most highly regarded food products in West Africa and particularly Nigeria as virtually all her ethnic groups feed on it; hence its close integration into the socio-cultural, economic and religious aspect of life such as marriage where some tubers of yam are presented to the bride family in accordance to the customs of the people (Odior et al, 2012).

\section{Pounded yam production}

Yam tuber, which is popular in most part of the world is often consumed in Africa. This can be processed into pounded yam 
for consumption. Although concentrated in Nigeria, the largest producer of yam in the world, the yam eating zones stretch from western Cote d'Ivoire to Cameroon. This plant is characterized by a great degree of natural genetic diversity adapted to a wide range of production conditions within the region (DEGRAS, 1986). Yam varieties generally achieve high yields (10 to 20 tons per hectare) and many have excellent storage properties in contrast to cassava. They generally have more stringent growing requirements than cassava as concerns both soil quality (high potassium level is needed) and cultivation techniques. Yam growing also has a high cost in terms of plant material. Using the traditional method, up to one-third of the harvest must be retained for use as seed-yam (Pierre-Marie, 1998).

Yam has been relatively neglected by agricultural researchers and up to date result that can raise productivity have been far limited compared to cassava the other major root crop (PierreMarie, 1998).

\section{Yam tubers}

Yams are an excellent source of potassium, with twice the amount as found in a multi-sized banana. They are also a good source of Vitamin C, B6, folate, iron, and magnesium. Yams are high in starch and contain an enzyme, alpha amylase, which converts starch to sugar as the tuber matures, is stored, or when heated. According to researchers at Brigham Young University, curing yams by storing them at $29^{\circ} \mathrm{C}\left(85^{\circ} \mathrm{F}\right)$ for four to six days immediately after harvest, increases the concentration of this enzyme (bringhamyounguniversity.com). Curing also appears to heal small surface scratches, decreasing the risk of rotting. Raw yams, like lima beans, contain glycosides, natural chemicals that breakdown into hydrogen cyanide in the stomach or when it is heated.

\section{Yam varieties}

Yams are economically useful plants belonging to the genus Dioscorea [4]. There are many varieties of yam which are differentiated by varying characteristics such as the direction of stem twines (clockwise or counterclockwise), the shape and colour of the leaves, stem and tubers, and the cooking quality of the tubers. The yam tuber is economically the most important part of the plant. The structure is extremely variable, depending on the species. Most yam tubers, however, are cylindrical in shape and the weight of individual tubers range from $200 \mathrm{~g}$ to $50 \mathrm{~kg}$ (Asiedu, 1989).

\section{Types of yam pounding machines}

The Pounding machine applies either torque or reciprocating force on a piece of solid for the purpose of changing its form from the solid state to a semi-solid nature. There are two types of pounding and they are: Impact (Reciprocating) pounding; rotary (torque) pounding.

The impact (reciprocating) pounding modes reciprocate in its operation. The mortar and pestle mode of pounding is classified under this class. The design uses the combination of both rotary and the reciprocating mode of pounding with the rotary mechanism incorporated at the mortar sent. Rotary pounding mode involved the crushing of boiled yam through rotary twisting force (torque) produced from a motor through pulleys and a propeller shaft connected to the blades. It is on this principle that the existing yam pounders are based (Figure 1).

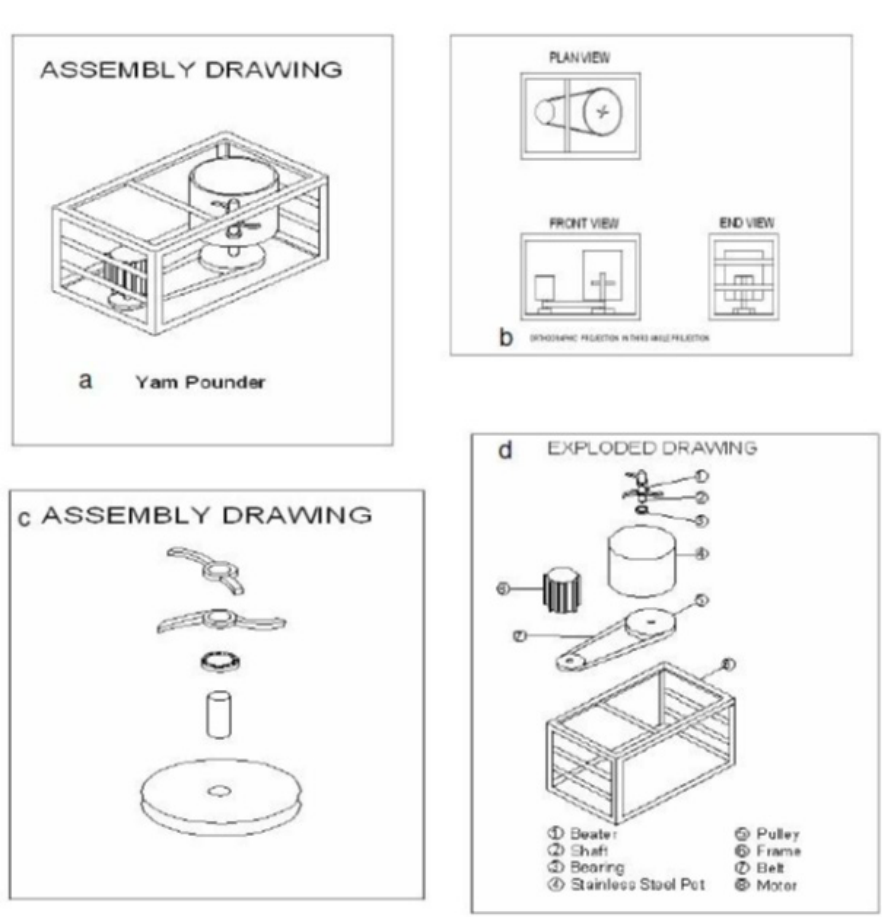

Figure 1: Component Elements of the Yam Pounding Machine (TISRD, 2008). 
The parts of the yam pounding machine: Lightweight materials are necessary for the development of mechanical systems $[5,6]$.

The shaft: The shaft which is made of mild steel was designed to transmit power to the yam beaters in the bowl to perform the yam pounding operation.

Pulley: The primary function of the pulley is to reduce the original speed of the electric motor to the required speed. The material selected for this pulley is mostly cast iron.

The yam beaters: The yam beaters are two blades made of stainless-steel material and they are the main components that do the real pounding of the yam. These are two bars designed and joined together at angle $90^{\circ}$ to each other at the center and they rotate together through angle $360^{\circ}$ while pounding the cooked slices of yam.

The bowl: The bowl consists of the yam beaters which perform the pounding operation in a chamber of the bowl. It is made of stainless-steel material with a volume of $0.018 \mathrm{~m}^{3}$.

The frame: The frame forms the housing of the whole components, including the electric motor. It has to be rigid to withstand all the forces generated in the components during the pounding operation.

\section{Effect of healthy yam processing}

Jimoh, et al., [7] presented an analysis of the medicinal effect of healthy carbohydrate processing.

The effect of yam processing was studied, and it is discovered to have an effect on the glycemic response to white yam (Dioscorea rotunda) meals. Postprandial glycemic response to food can be affected by the method of food preparation. The effect of processing on yam, a staple food in Nigeria, was studied in 24 healthy nondiabetic Nigerians. The postprandial glycemic indices of peak plasma glucose (PPG), maximum increase in plasma glucose (MIPG), 2-hour postprandial plasma glucose level (2HPPG), incremental area under glucose curve (IAUGC) and glycemic index (GI) were determined for boiled yam, pounded yam and yam flour (amala) after eating a measured amount of $50 \mathrm{~g}$ of digestible carbohydrate as recommended by FAO/WHO. Despite undergoing more processing, food prepared from yam flour showed better postprandial glycemic response indices as compared with other study foods. Yam flour submitted to more processing showed better indices than the other yam-based product compared. Yam based products, particularly yam flour, can be recommended for diabetic Nigerians as a substitute to eating monotonous beans-based products. The above analysis shows that well-processed yam can be a good supplement in the fight against widespread diabetes. After thorough examination and analysis, this project aims to provide this project presents the processing of yam to produce pounded yam using a pounding machine an alternative to the pounded yam from yam flour. In order to facilitate the processing of yam for consumption, a yam pounding machine is been developed using mainly some locally sourced materials. This project thus looks at the use of stainless steel to produce the parts that will have direct contact with the yam using the rotary motion of the yam beaters that will produce the normal crushing and turning as well as mixing in order to get the local texture of the pounded yam. All this in other to facilitate healthy processing of yam into of pounded yam.

\section{Methodology}

\section{Operational principle}

The Principle of yam pounding machine is like that of blender and digester. It comprises majorly of a prime mover which is mostly an electric motor and a transmission mechanism to transmit power and also to reduce speed. Belt and pulley are used for transmission and reduction of speed at the same time. This power is transmitted to a shaft with a blade able to both cut the yam and mix it. The yam pounding machine is designed and developed to hygienically process yam and it is designed to pound variable weight of cooked yams for domestic consumption. The machine consists of the following major components: the shaft, bearings, automatic gear electric motor, yam beater, bowl and the frame. The yam beater or blade is located on the upper edge of the shaft which is connected directly to the electric motor system. During the pounding operation, the slices of already cooked yam are loaded into the potlike pounding chamber and covered with the pounding chamber cover. The electric motor transmits power directly to the shaft through its armature section, as the shaft rotates it actuates the yam beater, which starts pounding the yams in the yam pounding chamber. The pot or pounding chamber bears the shaft and the beaters. The operational stages in yam pounding include; washing the yam tuber, peeling, slicing, parboiling and pounding using the pounding machine before packing the pounded yam [8].

\section{Machine components and material selection}

The machine components are the unit components of the machine that are assembled to form the entire machine. This includes frame, stainless pot, pulleys, shaft, electric motor, pounding blades, switch, cable wires etc.

For material selection, the major component of this machine and its material selection are:

- $\quad$ Pulley material selection: The main aim of the pulley is to reduce the original speed of the electric motor. The material selection for the pulley is steel.

- $\quad$ The machine frame: It gives the entire system support; the frame is known for housing the entire components of the machine. The frame withstands all the vibrating effects from the component of the machine during operation. Angle bars are used for constructing the frame. 
- Belt material selection: The main aim of the belt is to transmit power from one level to another in the machine. A35 Belt was selected for the pulley because it has a considerable high coefficient of friction and strength.

- Shaft material selection: The shaft is made up of stainless steel; the shaft is a major component of the machine which transmits power from one unit of the machine to another.

- Yam beaters: The yam beaters are two blades made of stainless-steel material and they are the main components that do the real pounding of the yam. These are two bars designed and joined together at angle $180^{\circ}$ to each other at the center and they rotate together through angle $360^{\circ}$ while pounding the cooked slices of yam.

- $\quad$ Pounding bowl: The pounding bowl consists of the yam beaters which perform the pounding operation in a chamber of the bowl. It is made of stainless-steel material.

- Switch: this is the component that regulates the electric supply, it controls the on and off of the machine.

- Wire: materials that conducts electricity into the motor for the functioning of the machine.

\section{Design analysis of the components}

In order to analyze components, we first determine the density of yam, which are $1250 \mathrm{~kg} / \mathrm{m}^{3}$ and $1950 \mathrm{~kg} / \mathrm{m}^{3}$ before and after boiling respectively. This figure has been experimented and determined by Osueke, 2010 and have been used in various works such as that of Odior et al, (2012) analysis of production capacity of yam flour for producing firm using a mathematical model.

\section{Determination of crushing force and power requirement}

The crushing force is the force required to masticate the yam to fine desired texture. Let the crushing pressure be denoted by $\mathrm{p}_{\mathrm{y}}$

$$
\text { Then crushing pressure, } p_{y}=\rho_{(b \times g \times h)}
$$

Where: $\rho_{\mathrm{b}}=$ density of boiled yam $=1950 \mathrm{~kg} / \mathrm{m}^{3} \mathrm{~s}, \mathrm{~g}=$ acceleration due to gravity $=9.81 \mathrm{~m} / \mathrm{s}^{2}$

$\mathrm{h}=$ height of the beater $=0.11 \mathrm{~m}$, pressure $\left(\mathrm{p}_{\mathrm{y}}\right)=1950 \times 9.81 \mathrm{x}$ $0.11, \mathrm{p}_{\mathrm{y}}=2.104 \times 103 \mathrm{n} / \mathrm{m}^{2}$

The force acting on the edge of the beater in contact with the yam is given by equation (2)

$$
\mathrm{N}_{\mathrm{i}}=\mathrm{p}_{\mathrm{y}} \times \mathrm{A}_{\mathrm{e}}
$$

Where: $\mathrm{N}_{\mathrm{i}}=$ force acting on the surface area of the beater in contact with the yam, Substituting the value of pressure $\left(p_{y}\right)=2.104$ $\mathrm{x} 103 \mathrm{n} / \mathrm{m}^{2}$ and area of beater from beater design $\left(A_{\mathrm{e}}\right)=0.022 \mathrm{~m}^{2}$ into equation (2),

$$
\mathrm{N}_{\mathrm{i}}=46.3 \mathrm{~N}
$$

Torque $\mathrm{T}=$ force $\mathrm{x}$ distance of the beater from the Centre of pivot,

$$
\mathrm{T}=\mathrm{N}_{\mathrm{I}} \mathrm{Xd} \mathrm{d}_{\mathrm{b}}
$$

Substituting the value force acting on the surface area of the beater in contact with the yam $(\mathrm{Ni})$ and the distance of the beater from the centre of pivot $\left(\mathrm{d}_{\mathrm{b}}\right)=0.11 \mathrm{~m}$ into eq.3, $\mathrm{T}=5.09 \mathrm{Nm}$

The power requirement to operate the machine. Power $(\mathrm{P})=$ Torque (T) x Angular speed (w)

Where: $\mathrm{w}=2 \pi \mathrm{N} / 60$

$\mathrm{P}=\mathrm{T} \times(2 \pi \mathrm{N} / 60)$

For a better performance, an optimal speed of 450rpm was chosen and a factor of safety 3.0 was also chosen for reliability purpose. Substituting the valve of optimal speed(450rpm) and torque $(5.09 \mathrm{Nm})$ into equation $6, \mathrm{P}=240$ watt. Also, by considering the chosen factor of safety, which is 3.0 , the minimum power requirement for the design is $\mathrm{P}=720$ watts.

Recall that, 1 horsepower $=746$ watts.

Therefore, an electric motor of $1 \mathrm{hp}$ with speed 1440rpm was chosen.

\section{Machine frame design}

The main purpose of the frame is to house the whole component, creating an attachment for the motor to hold it from extreme vibration and a compartment for the pot to seat. Angle bars of $40 \mathrm{~mm} \times 40 \mathrm{~mm} \times 30 \mathrm{~mm}$ made of mild steel was used throughout and thoroughly welded.

\section{Belt design}

The major use of the belt is to transmit motion from the pulley on the motor to that on the shaft connected to the pounding pot. The center to center distance of both pulleys is determined by equation 7 .

$$
x=\max \left(\frac{3 D_{e}}{2}+\frac{D_{b}}{2}\right)(7)
$$

Substituting the value of the diameter of electric motor pulley, De $(0.075 \mathrm{~m})$ and diameter of bowl pulley, $\mathrm{D}_{\mathrm{b}}(0.230 \mathrm{~m})$ into equation 7. $\mathrm{D}_{\mathrm{e}}=75 \mathrm{~mm}=0.075 \mathrm{~m} ; \mathrm{D}_{\mathrm{b}}=230 \mathrm{~mm}=0.230 \mathrm{~m}: \mathrm{x}=227.5 \mathrm{~mm}$

However, a center distance of $300 \mathrm{~mm}$ was chosen for better performance: $\mathrm{x}=300 \mathrm{~mm}=0.3 \mathrm{~m}$

Then the length of the belt is given by the mathematical expression,

$$
L=\frac{\pi\left(D_{e}+D_{b}\right)}{2}+2 x+\frac{\left(D_{e}+D_{b}\right)^{2}}{2}(8)
$$

Substituting the value of $\mathrm{De}(0.075 \mathrm{~m})$ and $\mathrm{Db}(0.230 \mathrm{~m})$ into equation $8, \mathrm{~L}=1125 \mathrm{~mm}$

Hence A35 Belt was selected for the pulley. 
Shaft design: The shaft is subjected to a torque or twisting moment and as a result, shearing stress is produced in the shaft. The shear stress varies from zero in the axis to a maximum at the outside surface of the shaft. The shear stress produced in the solid circular shaft is given as:

$$
T_{\max }=\frac{\sigma_{\max } I_{p}}{R} \quad \text { (B) (9) }
$$

$\mathrm{T}_{\max }=$ maximum twisting moment $(\mathrm{Nm}), \sigma_{\max }=$ maximum shear stress $(\mathrm{MPa}), \mathrm{R}=$ radius of shaft $(\mathrm{mm})$.

\section{Beater design}

The effective area of the beater is calculated thus;

$$
\mathrm{A}=\mathrm{BH}+\mathrm{bh}
$$

Where: $\mathrm{A}=$ effective area of the beater, $\mathrm{B}=$ width of beater, $\mathrm{h}=$ height of beater

$\mathrm{H}=$ total length of beater and to calculate the value of $\mathrm{b}$ we use equation

$$
\mathrm{b}=(\mathrm{H}-\mathrm{B}) / 2
$$

Where $\mathrm{B}=0.08 \mathrm{~m}, \mathrm{H}=0.2 \mathrm{~m}, \mathrm{~b}=0.06 \mathrm{~m}$ and $\mathrm{h}=0.11 \mathrm{~m} ; \mathrm{A}=\mathrm{BH}$ $+\mathrm{bh}$

The volume of space occupied by the beater inside the bowl is given as:

$$
\begin{aligned}
& V_{b}=A h \\
& V=2.42 \times 10^{-3} \mathrm{~m}^{3}
\end{aligned}
$$

Bearing design and selection: Ball radial bearing was chosen for this work because of its capability and suitability towards the load. The specific static load rating or capacity is given by

$$
C_{0}=\frac{1}{5} \times k_{0} \times i \times z \cos \alpha D_{w}^{2}
$$

Where: $\mathrm{C}_{0}=$ specific static load rating or capacity $=10 \mathrm{KN} ; \mathrm{K}_{0}=$ factor depending on the type of bearing $=12.3 ; \mathrm{D}_{\mathrm{w}}=$ diameter of the ball; $\alpha=$ Nominal angle of contact $=0 ; i=$ number of rows of ball in any one bearing $=1 ; z=$ number of balls per row in the groove $=6$

$$
k_{0}=\frac{Q_{\max }}{D_{w}^{2}}
$$

$\mathrm{Q}_{\max }=$ maximum bearing load

And the above data [9] the ball diameter can be calculated

$$
D_{w}=\sqrt{\frac{C_{0} x_{5}}{k_{0} x_{i} x_{z} \cos \alpha}}
$$

Substituting the value of $\mathrm{C}_{0}=10 \mathrm{KN}, \mathrm{K}_{0}=12.3, \mathrm{i}=1, \mathrm{z}=6, \propto=0$ into equation 15

$$
\mathrm{D}_{\mathrm{w}}=26.03 \mathrm{~mm}
$$

The maximum bearing load $Q_{\max }$ is given by equation 16

$$
Q_{\max }=k_{0} \times D_{w}^{2}(16)
$$

Substituting the value of $\mathrm{k}_{\mathrm{o}}=12.3$ and $\mathrm{D}_{\mathrm{w}}=26.03 \mathrm{~mm}$ into equation 17

$$
Q_{\max }=k_{0} \times D_{w}^{2}=8333.33 \mathrm{~N}
$$

A bearing of 6204 was selected with outer diameter of $47 \mathrm{~mm}$ and inner diameter of $20 \mathrm{~mm}$.

\section{Manufacturing Processes of the Yam Pounding Machine}

The Manufacturing processes of the yam pounding machine includes the processes involved in using various production methods in producing the yam pounding machine. Various manufacturing processes were carried out during the fabrication, production and assembling of the component's parts of this machine. The processes involved in producing the machine are as follows: Marking out operation or procedure, cutting, welding, machining and assembling operation [10-15].

- Marking out operation is done to get the required shape and size of the design according to our dimensions in order to meet our expectation or aim; it is done or carried out by using tapes, marker, squares, Vernier caliper etc.

- Cutting Operation: Hacksaw: for cutting rectangular plates and circular bars and angle bars.

- Guillotine machine: for cutting of mark out sheet of stainless steel and mild steel into the required dimension or measurement.

\section{Welding, Machining and Assembling Operation}

The welding process is the system of using electric welding and electrode to join the material into shape. Machining operation was performed using a lathe machine was used in the machining operation; the shaft was machined to the required shape so that it can fit properly for use [15-20].

Assembling operation has to do with bringing together all the required part components to form a unit or a complete machine. The various materials are put in place in its various stipulated places. The angle bar used for the framework, the stainless-steel pot, the electric motor, the shaft, the pulley, the aluminum sheet used for covering the framework were all assembled in their various ways and positions.

\section{Safety Considerations}

The safety considerations in this work stem up from the fact that as an electromechanical device, injuries and damages are bound to occur, thus the safety precautions are as follows: 
- Ensure that all the electric components are thoroughly earthed

- Avoid hand contact with the pounding blade

- Avoid opening the pounding chamber when the machine is on

\section{Testing, Result and Discussion}

The fabricated yam pounding machine was tested by operating it with electricity. Yam of weight $3 \mathrm{~kg}$ was used and cut into small sizes. Two Species of cooked yams were tested with the machine by operating it to pound the cooked yams and it was discovered that the white yam, took a maximum time of two minutes fifty seconds, and the yellow yam, took a maximum time of three minutes. The white and the yellow yam were starchy after pounding. The pounded yam was firm and smooth in texture, compact with adequate hardness. After pounding the weight of the yam was $2.9 \mathrm{~kg}$. Machine efficiency is $96.7 \%$. The initial weight of the yam before pounding was $3 \mathrm{~kg}$ $(3000 \mathrm{~g})$ and the final weight of the pounded yam is $2.9 \mathrm{~kg}(2900 \mathrm{~g})$. The machine is of high productivity, efficient and also save time [20-25]. The major components that make up the yam pounder are the electric motor, belt, pulley, shaft, bowl (Stainless steel pot), bearing and beater. The machine was well evaluated to suit its usage. That is, the components parts. The makeup of the machine was duly selected to carrying out its purpose and making it easily operational to the users. The factor considered and evaluated were the weight of the motor, the thickness of pot and beater and the total weight of the machine. The machine was also observed while in operation and it was found that the resistance of the electric motor to the vibrations and its performance were satisfactory, pointing to the fact that a greater percentage of the vibrations set up during the pounding process are absorbed by the damper on the electric motor seating and the fan belt.

\section{Conclusion and Recommendation}

There are other possible challenges which the yam pounder can solve such as pounding of fufu, however, it is gratifying that to know that it has been proven to perform its function satisfactorily. The materials used for the fabrication were selected at a reasonable cost to produce a low-cost machine while still ensuring that the materials performed their function satisfactorily. The volume of yam pounded at a time is approximately enough to feed three or more people. It is recommended that all homes should procure at least a yam pounder to enable them to prepare a good and hygienic pounded yam thereby saving them from the strenuous and the traditional method of pounding yam. Also, young engineering graduates should be made to undergo training on technological skill acquisition such as the design and production of a machine such as this to enable them to be self-employed and, employer of labor thereby reducing the search for white-collar jobs.

\section{Acknowledgement}

None.

\section{Conflict of Interest}

No conflict of interest.

\section{References}

1. Uyanaga K, Adeoye AO, Ogbeide SE (2018) Production and characterization of organic solar cells. World Journal of Engineering, 15(4): 540-548.

2. MO Okwu, IO Adeyemi, Thank God E Boye, BO Ezurike (2016) Development of Water Hyacinth Briquetting Machine. International Journal of Scientific Research in Information Systems and Engineering (IJSRISE) 2(1): 43-47.

3. Ezurike Benjamin (2017) Modified Screw Jack for Lifting Operation in Industrial Setting. International Journal of Engineering and Technologies 13: 33-50.

4. Coursey O (1967) Yams Tropical Agricultural Series. Macmillan Press Limited, London.

5. Okwu MO, Otanocha OB (2018) Development of a Lightweight Briquetting Machine for Small and Medium Scale Enterprise. FUPRE Journal of Scientific and Industrial Research 2(1): 71-87.

6. Okwu MO, Emovon I (2018) Comparative Performance and Analysis of Fuel Briquette produced from Water Hyacinth Plant with Paraffin oil. Journal of Advancement in Engineering and Technology 6(2): 1-6.

7. Aderoba OA (2008) Development of a Yam Peeling and Slicing Machine for a Yam (Poundo Yam) Process Plant, B-Eng project report, The Federal University of Technology, Akure, Ondo State, Nigeria.

8. Odior AO, Orsarh ES (2008) Design and Constructionn of a Yam Pounding Machine. International Journal of Nature and Applied Sciences 4(3): 319-323.

9. Budynas, Nisbett (2008) Shigley's Mechanical Engineering Design, Mcgraw-hill companies $8^{\text {th }}$ edition pp. 15,351.

10. Achebo JI, Ogbu 0 (2009) Design and Manufacture of a Yam Pounding Machine, NJISS 8(2).

11. Asiedu JJ (1999) Processing tropical crops:A Technological Approach. Macmillan Press Limited, London.

12. Deul Schman D Aaron, et al (1985) Machine design: Theory and System handbook, McGac Hill book Company London.

13. DeutschmanD, Aron A (1985) Machine Design: Theory and System Handbook, Mcgraw Hill Book Company, London.

14. Gbasouzor AI, Mbunwe JM (2015) Development of a Motorized Yam Pounding Machine Design to Improve Standard of Living for Sustainable Economic Development in Nigeria. World Congress on Engineering, Vol. 2.

15. Harbart (2007) Kenwood: Power Splitters, Patent \& Design Journal 6159: 522.

16. Hans M (1984) Kolstee: Machine Design for Mechanical Technology, HRW Publishers. New York.

17. Martins AE (1970) Bending, forming and Shearing Journal of Institute of Mechanical Engineers. 4(3): 36-41.

18. MC Grawhills (1982) Encyclopedia of Science and Technology, Belt arrangements, New York.

19. Muller K, Ennis DM (1979) Rotatable designs in product development. Food Technology 33(7): 5-5.

20. MV Joshi (1976) Process Equipment Design, $2^{\text {nd }}$ Edition, Macmillan India Limited, pp. 180-188, 198-205, 360-371.

21. Niemann G (1978) Machine Elements: Design and calculations in Mechanical Engineering; Springer- Verlag Berlin Heidelberg, New York, pp. 219-224. 
22. Oweziem BU, Chinwuko EC, Ezeliora CD, Obaseki E (2015) Design, Fabrication and Characterization of an electric Powered yam pounding machine. America Journal of Mechanical Engineering and Automation 2(2): 26-35.

23. Oyenuga VA (1967) Agriculture in Nigeria: An introduction. Ibadan University Press, Ibadan, pp. 112-118.
24. Redford GD (1973) Mechanical Engineering Design, Macmillan Press, London.

25. Toliyat HA, Kliman GB (2004) Handbook of Electric Motors, Second Edition: series on Environmental and Energy, CRC press USA 1: 523. 